\title{
ANALISIS FAKTOR FAKTOR YANG MEMPENGARUHI MOTIVASI PETANI DALAM BERUSAHATANI TEBU (STUDI KASUS DI DESA KERTOSARI KECAMATAN ASEMBAGUS KABUPATEN SITUBONDO)
}

\author{
Zeinur Rosyid \\ Prodi Agribisnis, Universitas Abdurachman Saleh Situbondo, Situbondo \\ *Email Korespondensi: acinkbechkam@gmail.com
}

\begin{abstract}
Abstrak
Penelitian ini bertujuan (1) untuk mengetahui hubungan antara variabel pembentuk motivasi $(\mathrm{X})$ dengan variabel motivasi (Y) dalam berusahatani tebu (2) untuk mengetahui pengaruh variabel faktor pembentuk motivasi $(\mathrm{X})$ terhadap variabel motivasi $(\mathrm{Y})$ dalam berusahatani tebu (3) untuk mengetahui rekomendasi alternatif untuk meningkatkan motivasi petani dalam berusahatani tebu. Metode analisa data yang digunakan dalam penelitian adalah uji rank spearman dan uji t. Hasil penelitian menunjukkan bahwa hubungan faktor internal pembentuk motivasi dengan motivasi kebutuhan petani yang memiliki hubungan kuat adalah pendapatan, sedangkan hubungan faktor eksternal yang memiliki hubungan kuat adalah kebijakan pemerintah. Hasil uji t menunjukkan faktor internal pembentuk motivasi yang berpengaruh signifikan terhadap motivasi kebutuhan petani adalah pendapatan dan umur, sedangkan faktor eksternal pembentuk motivasi yang berpengaruh signifikan adalah lingkungan sosial.
\end{abstract}

Kata Kunci: Motivasi Petani, Tebu, Usahatani

\begin{abstract}
This study aims (1) to determine the relationship between the motivating variable (X) and the motivation variable $(Y)$ in cultivating sugarcane (2) to determine the effect of the motivational forming factor variables $(X)$ on the motivation variable $(Y)$ in cultivating sugar cane (3) to find alternative recommendations to increase the motivation of farmers in sugarcane farming. The data analysis method used in the study was the Spearman rank test and the $t$ test. The results showed that the relationship between the internal factors forming motivation and the motivation of farmers' needs which had a strong relationship was income, while the relationship between external factors that had a strong relationship was government policy. The results of the $t$ test show that the internal factors that have a significant effect on the motivation for farmers' needs are income and age, while the external factors that have a significant effect on motivation are the social environment.
\end{abstract}

Keywords: Motivation of Farmers, Sugarcane, Farming

\section{PENDAHULUAN}

Indonesia dikenal sebagai negara agraris yang berarti negara yang mengandalkan sektor pertanian baik sebagai sumber mata pencaharian maupun sebagai penopang pembangunan. Sektor pertanian meliputi subsektor tanaman bahan makanan, subsektor holtikultura, subsektor perikanan, subsektor peternakan, dan subsektor kehutanan. Namun produktivitas pertanian masih jauh dari harapan. Salah satu faktor penyebab kurangnya produktivitas pertanian adalah sumber daya manusia yang masih rendah dalam mengolah lahan pertanian 
dan hasilnya. Mayoritas petani di Indonesia masih menggunakan sistem manual dalam pengolahan lahan pertanian (Sadono Sukirno, 2006).

Tabel 1. Data Luas Areal Lahan Tebu Setiap Kabupaten di Jawa Timur

\begin{tabular}{|c|l|c|c|c|c|c|}
\hline No. & $\begin{array}{c}\text { Nama } \\
\text { Kabupaten }\end{array}$ & $\begin{array}{c}\mathbf{2 0 1 3} \\
\text { (Ton) }\end{array}$ & $\begin{array}{c}\mathbf{2 0 1 4} \\
\text { (Ton) }\end{array}$ & $\begin{array}{c}\mathbf{2 0 1 5} \\
\text { (Ton) }\end{array}$ & $\begin{array}{c}\mathbf{2 0 1 6} \\
\text { (Ton) }\end{array}$ & $\begin{array}{c}\mathbf{2 0 1 7} \\
\text { (Ton) }\end{array}$ \\
\hline 1 & Pacitan & - & - & - & - & - \\
\hline 2 & Ponorogo & 1.789 & 1.776 & 9.809 & 6.260 & 5.832 \\
\hline 3 & Trenggalek & 698 & 624 & 3.656 & 1.816 & 1.388 \\
\hline 4 & Tulungagung & 985 & 5.947 & 49.802 & 32.126 & 31.698 \\
\hline 5 & Blitar & 6.448 & 6.484 & 36.630 & 37.152 & 36.724 \\
\hline 6 & Kediri & 23.747 & 26.133 & 163.921 & 144.390 & 143.519 \\
\hline 7 & Malang & 44.317 & 44.317 & 277.489 & 221.205 & 218.361 \\
\hline 8 & Lumajang & 12.504 & 12.550 & 70.481 & 100.885 & 100.041 \\
\hline 9 & Jember & 6.495 & 7.578 & 44.296 & 47.218 & 46.374 \\
\hline 10 & Banyuwangi & 324 & 517 & 2.615 & 32.503 & 29.659 \\
\hline 11 & Bondowoso & 6.449 & 6.853 & 28.863 & 21.840 & 21.092 \\
\hline 12 & Situbondo & 8.822 & 8.022 & 47.563 & 39.052 & 38.304 \\
\hline 13 & Probolinggo & 3.662 & 4.212 & 17.953 & 19.016 & 18.267 \\
\hline 14 & Pasuruan & 3.719 & 4.286 & 25.562 & 21.854 & 21.106 \\
\hline 15 & Sidoarjo & 6.266 & 5.691 & 28.858 & 23.461 & 22.713 \\
\hline
\end{tabular}

Sumber: Dinas Perkebunan Provinsi Jawa Timur

Tebu merupakan salah satu komiditi perkebunan yang memiliki peran strategis untuk perekonomian Indonesia. Industri gula berbahan baku tebu merupakan salah satu sumber pendapatan bagi ribuan petani tebu dan pekerja di industri gula. Gula juga merupakan salah satu kebutuhan pokok bagi sebagian besar masyarakat dan sumber kalori yang relatif murah (Badan Pusat Statistik, 2018). Jawa Timur merupakan salah satu bagian penyumbang gula terbesar di Indonesia. Dalam lima tahun terakhir produksi gula terus mengalami perubahan berdasarkan data luas lahan perkebunan tebu Provinsi Jawa Timur menunjukkan adanya situasi yang berfluktuasi.

Guna mendukung peningkatan produksi tanaman tebu, hendaknya pemerintah memberikan masukan atau arahan yang sangat dibutuhkan oleh petani tebu sebagai motivasi agar petani meningkatkan produksi tebu sebagai bahan baku gula pasir. Apabila para petani termotivasi, maka kemungkinan besar jumlah produksi tebu akan meningkat yang berdampak pada jumlah proses produksi gula. Memang telah banyak penelitian tentang tebu dan petani tebu sebelumnya, namun di sini peneliti ingin mengetahui lebih jauh tentang motivasi apa yang mendorong petani masih mau menanam tebu dibandingkan dengan padi yang mempunyai waktu pendek dalam proses usahatani, sedangkan tebu mempunyai waktu yang relatif lama. 
BPS (2016) pada buku Statistik tebu Indonesia 2018 mengatakan bahwa peningkatan konsumsi gula di Indonesia dari tahun ke tahun memberikan peluang yang luas bagi peningkatan kapasitas produksi pabrik gula. Selain itu dari jumlah produksi gula di dalam negeri saat ini dirasakan belum mampu memenuhi kebutuhan gula di Indonesia. Di masa mendatang, pemerintah berupaya agar Indonesia dapat mencapai swasembada gula sebagai salah satu langkah menuju Ketahanan Pangan Nasional.

Pentingnya motivasi petani bagi petani membuat petani mendapatkan pendapatan yang lebih besar. Pabrik gula Asembagus dalam tahun 2016 dan 2017 mengalami perbaikan pabrik sehingga produksi gula mengalami penurunan. Perbaikan dalam pabrik gula Asembagus menyebabkan petani menjadi khawatir dalam berusahatani tebu, apabila panen atau tebang tanaman tebu akan digiling di pabrik gula Asembagus atau ke pabrik gula lain di Kabupaten Situbondo sehingga butuh biaya transportasi yang besar. Desa Kertosari Kecamatan Asembagus mempunyai 125 petani, pabrik gula Asembagus berkewajiban memberikan motivasi kepada petani agar tetap berusahatani tebu. Hal inilah yang melatar belakangi, mengapa penulis lebih tetarik untuk membahas topik: "Analisis FaktorFaktor yang Mempengaruhi Motivasi Petani Dalam Berusahatani Tebu (studi kasus di Desa Kertosari Kecamatan Asembagus Kabupate Situbondo)". Berdasarkan latar belakang masalah di atas, maka dapat dituliskan beberapa rumusan masalah sebagai berikut:

1.Bagaimana hubungan antara variabel faktor pembentuk motivasi $(\mathrm{X})$ dengan variabel motivasi (Y) dalam berusahatani tebu di Desa Kertosari Kecamatan Asembagus?

2.Bagaimana pengaruh variabel faktor pembentuk motivasi $(\mathrm{X})$ terhadap variabel motivasi (Y) dalam berusahatani tebu di Desa Kertosari Kecamatan Asembagus?

3.Alternatif apa yang digunakan untuk meningkatkan motivasi petani dalam berusahatani tebu di Desa Kertosari Kecamatan Asembagus?

\section{METODOLOGI PENELITIAN}

\section{Tempat dan Waktu Penelitian}

Pemilihan lokasi penelitian dilakukan secara sengaja dengan pertimbanganpertimbangan tertentu (Singarimbun, M \& Efendi, 1995). Lokasi penelitian dipilih secara sengaja (purposive) yaitu di Desa Kertosari Kecamatan Asembagus Kabupaten Situbondo. Penentuan sample dilakukan dengan metode purposive sampling yaitu di Desa Kertosari Kecamatan Asembagus. Desa Kertosari merupakan desa yang mayoritas petaninya berusahatani tanaman tebu. Waktu Penelitian juli-agustus 2020.

\section{Jenis dan Sumber Data}

Jenis data yang dikumpulkan dalam penelitian ini berupa data primer dan data sekunder. Data primer diperoleh secara langsung dari sumber atau objek yang sedang diteliti melalui observasi, pengisian kuesioner dan wawancara. Sedangkan data sekunder diperoleh dari literatur-literatur terkait yang diperoleh dari kantor Kabupaten situbondo, kantor kecamatan, BPS, serta sumber-sumber lain yang menunjang penelitian. 


\section{Populasi dan Sampel}

Pengambilan sampel didapatkan dari petani tebu di Desa Kertosari Kecamatan Asembagus. Metode pengambilan sampel dalam penelitian ini menggunakan simple random sampling. Sugiyono (2013) "Simple random sampling adalah pengambilan anggota sampel dari populasi yang dilakukan secara acak tanpa memperhatikan strata yang ada dalam populasi tersebut, cara demikian dilakukan bila anggota populasi dianggap homogen". Cara menghitung jumlah sampel menggunakan rumus slovin menurut (Husein Umar, 2013):

$$
\begin{aligned}
& \qquad n=\frac{N}{1+N e^{2}} \\
& \text { Keterangan: } \\
& \text { n: Jumlah sampel } \\
& \mathrm{N} \quad \text { : Jumlah populasi } \\
& \text { e2 : Taraf nyata atau batas kesalahan }
\end{aligned}
$$

Sampel yang digunakan dalam penelitian ini sebanyak 21 responden petani tebu. Teknik pengambilan sampel yang dilakukan dalam penelitian ini menggunakan teknik simple random sampling, dimana pengambilan sampel dilakukan secara acak karena semua populasi yang digunakan dalam penelitian ini dianggap sama.

\section{Teknik Pengumpulan Data}

Dalam penelitian ini pengumpulan data dilakukan dengan menggunakan teknik sebagai berikut :

1.Obeservasi yaitu cara pengumpulan data dengan melakukan pengamatan langsung terhadap sasaran penelitian untuk mendapatkan data-data yang berhubungan dengan kegiatan dan motivasi petani terhadap usahatani tebu. Teknik observasi diharapkan dapat menjelaskan atau menggambarkan secara luas dan rinci tentang masalah yang dihadapi.

2.Kuesioner merupakan teknik pengumpulan data yang dilakukan dengan cara memberi seperangkat pernyataan atau pertanyaan tertulis kepada responden untuk menjawab. Data yang ingin diperoleh peneliti yakni dengan cara memberi angket.

3.Wawancara adalah teknik pencarian data/informasi mendalam yang diajukan kepada responden/informan dalam bentuk pertanyaan susulan setelah teknik angket dalam bentuk pertanyaan lisan (Mahi M. Hikmat, 2011).

\section{Analisa Data}

Untuk mengetahui tingkat motivasi petani tebu di desa Kertosari dilakukan analisis secara statistik terhadap data dengan model rank Spearman, (Siegel, Sidney, Zanzawi Suyuti, \& Simatupang, Laudung, 2007). Untuk menghitung rs Spearman digunakan rumus sebagai berikut:

$$
r s=1-\frac{6 \sum D^{2}}{n\left(n^{2}-1\right)}
$$


Keterangan:

rs : Koefisien korelasi rank spearman

n : Jumlah responden/sampel

D2 : Selisih antara X dan Y (rangking dari variabel pengamatan)

6 : Merupakan angka konstan

Untuk menentukan kuat lemahnya korelasi digunakan batasan champion yang dikutip dari (Singarimbun, M \& Efendi, 1995) dengan ketentuan sebagai berikut :

1. Antara 0,00 sampai dengan 0,25 atau 0,00 sampai dengan $-0,25$ disebut No Association kondisi yang menunjukkan tidak adanya hubungan antara variabel $\mathrm{X}$ dan variabel Y.

2. Antara 0,26 sampai 0,50 atau $-0,26$ sampai dengan $-0,50$ disebut moderately low association yaitu kondisi yang menunjukkan hubungan yang lemah antara variabel $\mathrm{X}$ dan variabel $\mathrm{Y}$.

3. Antara 0,51 sampai dengan 0,75 atau $-0,51$ sampai dengan $-0,75$ disebut moderately high association yaitu kondisi yang menunjukkan hubungan yang lumayan kuat antara variabel $\mathrm{X}$ dan variabel $\mathrm{Y}$.

4. Antara 0,76 sampai dengan 1,00 atau -0,76 sampai dengan $-1,00$ disebut high association yaitu kondisi yang menunjukkan hubungan yang kuat antara variabel $\mathrm{X}$ dan variabel Y.

Untuk menguji tingkat signifikasi hubungan antara antara faktor-faktor pembentuk motivasi dengan motivasi kebutuhan petani terhadap berusahatani tebu, digunakan uji t dengan menggunakan rumus menurut (Siegel, Sidney et al., 1992):

$$
t=r s \sqrt{\frac{N-2}{1-r s^{2}}}
$$

Keterangan:

$\mathrm{t}$ : Nilai hitung

rs: Korelasi rank spearman

$\mathrm{N}$ : Jumlah responden/sampel

Sanusi (2011) mengemukakan bahwa "Dasar pengambilan keputusan adalah dengan menggunakan probabilitas signifikan", yaitu sebagai berikut:

1)Bila thitung $\geq$ ttabel atau - thitung $\leq-$ ttabel dan nilai signifikan $\mathrm{t}<$ tingkat signifikansi 5\% (0,05), maka Ho ditolak dan Ha diterima. Hal ini berarti ada pengaruh yang signifikan dari masing-masing variabel bebas terhadap variabel terikat secara parsial.

2)Bila thitung < ttabel atau - thitung $>-$ ttabel dan nilai signifikansi $t>$ tingkat signifikansi 5\% $(0,05)$, maka Ho diterima dan Ha ditolak. Hal ini berarti tidak ada pengaruh yang signifikan dari masing-masing variabel bebas terhadap variabel terikat secara parsial. 


\section{HASIL DAN PEMBAHASAN}

\section{Hasil Penelitian}

Analisis Hubungan dan Pengaruh antara Faktor Internal dan Eksternal dengan Motivasi Kebutuhan Petani dalam Berusahatani Tebu.

Analisis hubungan dan pengaruh yang dilakukan dalam penelitian ini menggunakan uji korelasi rank spearman (rs) dan uji t dengan bantuan program SPSS 22.0 for windows. Hasil uji analisis hubungan dan pengaruh antara faktor internal dan eksternal dengan motivasi kebutuhan petani dalam berusaha tani tebu di Desa Kertosari Kecamatan Asembagus Kabupaten Situbondo dapat dilihat pada Tabel 2 dan Tabel 3 sebagai berikut:

Tabel 2. Uji Hipotesis antara Faktor Pembentuk Motivasi dengan Motivasi Kebutuhan Petani dalam Berusahatani Tebu

\begin{tabular}{|c|c|c|c|c|c|c|}
\hline \multirow{3}{*}{$\begin{array}{c}\text { Faktor Pembentuk } \\
\text { Motivasi } \\
\text { (X) }\end{array}$} & \multicolumn{6}{|c|}{$\begin{array}{l}\text { Motivasi Kebutuhan Petani dalam Berusahatani Tebu } \\
\qquad(\mathrm{Y})\end{array}$} \\
\hline & \multicolumn{2}{|c|}{$\begin{array}{l}\text { Kebutuhan Fisiologis } \\
\left(\mathrm{Y}_{1}\right)\end{array}$} & \multicolumn{2}{|c|}{$\begin{array}{l}\text { Kebutuhan Sosiologis } \\
\left(\mathrm{Y}_{2}\right) \\
\end{array}$} & \multicolumn{2}{|c|}{$\begin{array}{l}\text { Kebutuhan Psikologis } \\
\left(\mathrm{Y}_{3}\right)\end{array}$} \\
\hline & Hubungan & Pengaruh & Hubungan & Pengauh & Hubungan & Pengaruh \\
\hline $\operatorname{Umur}\left(\mathrm{X}_{1}\right)$ & Lemah & - & Lemah & Pengaruh & Lemah & - \\
\hline Pendidikan $\left(\mathrm{X}_{2}\right)$ & - & - & - & - & Lemah & - \\
\hline Luas Lahan $\left(\mathrm{X}_{3}\right)$ & Agak Kuat & - & - & - & - & - \\
\hline Pendapatan $\left(\mathrm{X}_{4}\right)$ & Agak Kuat & Pengaruh & - & Pengaruh & Lemah & - \\
\hline Lingkungan Sosial $\left(\mathrm{X}_{5}\right)$ & - & - & Agak Kuat & Pengaruh & - & - \\
\hline Lingkungan Ekonomi $\left(\mathrm{X}_{6}\right)$ & - & - & - & - & - & - \\
\hline Kebijakan Pemerintah $\left(\mathrm{X}_{7}\right)$ & Agak Kuat & - & - & - & - & - \\
\hline
\end{tabular}

Sumber: Lampiran 5, 2020.

Tabel 3. Hasil Uji Hipotesis antara Faktor Pembentuk Motivasi dengan Motivasi Kebutuhan Petani dalam Berusahatani Tebu

\begin{tabular}{|c|c|c|c|c|c|c|c|c|c|}
\hline \multirow{3}{*}{$\begin{array}{l}\text { Faktor Pembentuk } \\
\text { Motivasi } \\
\text { (X) }\end{array}$} & \multicolumn{9}{|c|}{$\begin{array}{l}\text { Motivasi Kebutuhan Petani dalam Berusahatani Tebu } \\
\text { (Y) }\end{array}$} \\
\hline & \multicolumn{3}{|c|}{$\begin{array}{c}\text { Kebutuhan Fisiologis } \\
\left(\mathrm{Y}_{1}\right)\end{array}$} & \multicolumn{3}{|c|}{$\begin{array}{l}\text { Kebutuhan Sosiologis } \\
\qquad\left(\mathrm{Y}_{2}\right)\end{array}$} & \multicolumn{3}{|c|}{$\begin{array}{l}\text { Kebutuhan Psikologis } \\
\qquad\left(\mathrm{Y}_{3}\right)\end{array}$} \\
\hline & Rs & $t_{\text {bitung }}$ & sig & Rs & $t_{\text {bitung }}$ & Sig & Rs & $t_{\text {hitung }}$ & sig \\
\hline $\operatorname{Umur}\left(\mathrm{X}_{1}\right)$ & $-0,346$ & $-0,206$ & 0,840 & $-0,422$ & $-2,938$ & 0,012 & $-0,427$ & $-0,653$ & 0,525 \\
\hline Pendidikan $\left(\mathrm{X}_{2}\right)$ & 0,188 & 0,098 & 0,924 & 0,220 & $-0,570$ & 0,579 & 0,489 & 1,277 & 0,224 \\
\hline Luas Lahan $\left(\mathrm{X}_{3}\right)$ & 0,593 & $-1,659$ & 0,121 & 0,239 & 1,423 & 0,178 & 0,237 & $-0,397$ & 0,698 \\
\hline Pendapatan $\left(\mathrm{X}_{4}\right)$ & 0,719 & 2,703 & 0,018 & 0,204 & $-2,256$ & 0,042 & 0,324 & 0,822 & 0,426 \\
\hline Lingkungan Sosial $\left(\mathrm{X}_{5}\right)$ & $-0,083$ & $-0,490$ & 0,632 & 0,576 & 3,972 & 0,002 & 0,217 & 1,338 & 0,204 \\
\hline Lingkungan Ekonomi $\left(\mathrm{X}_{6}\right)$ & -0.070 & $-1,418$ & 0,180 & 0,221 & $-0,119$ & 0,907 & 0,060 & $-0,335$ & 0,743 \\
\hline Kebijakan Pemerintah $\left(\mathrm{X}_{7}\right)$ & 0,592 & 0,641 & 0,533 & 0,174 & 0,419 & 0,682 & 0,221 & 0,049 & 0,962 \\
\hline
\end{tabular}

Sumber: Lampiran 5, 2020. 


\section{Pembahasan \\ Hubungan dan Pengaruh antara Umur (X1) dengan Motivasi Kebutuhan Petani (Y)}

Hubungan antara umur dengan kebutuhan fisiologis dapat dilihat dari nilai rs yang diperoleh sebesar -0,346 berada di antara batasan -0,26 sampai -0,50, dimana kondisi tersebut dinamakan dengan moderately low assocition. Selanjutnya hasil uji t untuk umur dilihat dari nilai t hitung sebesar -0,206 dan t tabel 2,160, sehingga diperoleh bahwa $t$ hitung $-0,206>t$ tabel $-2,160$ dan tingkat signifikansi 0,840 > 0,05 maka Ho diterima dan Ha ditolak, artinya tidak ada pengaruh signifikan antara umur petani dengan motivasi kebutuhan fisiologis. Hal ini menunjukkan bahwa perbedaan umur atau bertambahnya umur responden tidak berhubungan dengan motivasi kebutuhan fisiologis dalam berusahatani tebu. Petani yang memiliki umur yang lebih tua belum tentu memiliki motivasi kebutuhan fisiologis yang lebih tinggi dibandingkan dengan petani yang berumur lebih muda dan begitupun sebaliknya. Karena petani yang memiliki umur yang muda ataupun tua sama-sama memiliki keinginan atau dorongan untuk mempebaiki ekonomi dalam keluarganya.

Hubungan antara umur dengan kebutuhan sosiologis dapat dilihat dari nilai rs yang diperoleh sebesar $-0,442$ berada di antara batasan -0,26 sampai -0,50, dimana kondisi tersebut dinamakan dengan moderately low assocition. Selanjutnya hasil uji t untuk umur dilihat dari nilai thitung sebesar -2,938 dan ttabel 2,160, sehingga diperoleh bahwa thitung -2,938< ttabel -2,160 dan tingkat signifikansi 0,012 < 0,05 maka Ho ditolak dan Ha diterima, artinya ada pengaruh signifikan antara umur petani dengan motivasi kebutuhan sosiologis. Hal ini sesuai dengan hipotesa kedua (H2) yang mengatakan bahwa terdapat pengaruh antara umur dengan motivasi kebutuhan sosiologis. Hal ini menunjukkan bahwa perbedaan umur atau bertambahnya umur responden memiliki hubungan dengan motivasi kebutuhan sosiologis dalam berusaha tani tebu. Perbedaan umur petani bisa dijadikan sebagai tolak ukur untuk mengetahui seberapa mampu petani bisa bekerja dan memiiki kemauan untuk bisa bekerjasama dengan siapapun dalam berusahatani tebu. Petani yang berumur tua cenderung lebih berpengalaman dalam membuka kesempatan untuk bertukar pendapat, bekerjasama ataupun bersosial dengan petani lain yang berguna untuk saling mendukung dalam berusaha tani tebu sehingga dapat mencapai hasil produksi yang maksimal dibandingkan dengan petani yang memiliki umur yang lebih muda.

Hubungan antara umur dengan kebutuhan psikologis dapat dilihat dari nilai rs yang diperoleh sebesar $-0,427$ berada di antara batasan -0,26 sampai -0,50, dimana kondisi tersebut dinamakan dengan moderately low assocition. Selanjutnya hasil uji t untuk umur dilihat dari nilai thitung sebesar -0,653 dan ttabel 2,160, sehingga diperoleh bahwa thitung $-0,653>$ ttabel $-2,160$ dan tingkat signifikansi 0,525 > 0,05 maka Ho diterima dan Ha ditolak, artinya tidak ada pengaruh signifikan antara umur petani dengan motivasi kebutuhan psikologis. Hal ini menunjukkan bahwa perbedaan umur atau bertambahnya umur responden tidak berhubungan dengan motivasi kebutuhan psikologis dalam berusaha tani tebu. Karena petani yang memiliki umur tua ataupun yang lebih muda sama-sama memilki keinginan ataupun motivasi agar statusnya lebih tinggi dari petani yang 
lain atau minimal memiliki status yang setara dengan petani yang juga sama-sama berusaha tani tebu.

\section{Hubungan dan Pengaruh antara Pendidikan (X2) dengan Motivasi Kebutuhan Petani (Y)}

Hubungan antara pendidikan dengan kebutuhan fisiologis dapat dilihat dari nilai rs yang diperoleh sebesar 0,188 berada di antara batasan 0,00 sampai 0,25, dimana kondisi tersebut dinamakan dengan no assocition. Selanjutnya hasil uji $\mathrm{t}$ untuk pendidikan dilihat dari nilai thitung sebesar 0,098 dan ttabel 2,160, sehingga diperoleh bahwa thitung 0,098 < ttabel 2,160 dan tingkat signifikansi 0,924 > 0,05 maka Ho diterima dan Ha ditolak, artinya tidak ada pengaruh signifikan antara pendidikan dengan motivasi kebutuhan fisiologis. Hal ini menunjukkan bahwa tinggi rendahnya pendidikan responden tidak berhubungan dengan motivasi kebutuhan fisiologis dalam berusahatani tebu. Tinggi rendahnya tingkat pendidikan yang dimiliki oleh responden petani tidak akan mendorong petani untuk dapat berpikir lebih maju dan lebih rasional.

Hubungan antara pendidikan dengan kebutuhan sosiologis dapat dilihat dari nilai rs yang diperoleh sebesar 0,220 berada di antara batasan 0,00 sampai 0,25, dimana kondisi tersebut dinamakan dengan no assocition. Selanjutnya hasil uji t untuk pendidikan dilihat dari nilai thitung sebesar -0,570 dan ttabel 2,160, sehingga diperoleh bahwa thitung $-0,570>$ ttabel $-2,160$ dan tingkat signifikansi $0,579>0,05$ maka Ho diterima dan Ha ditolak, artinya tidak ada pengaruh signifikan antara pendidikan dengan motivasi kebutuhan sosiologis. Hal ini menunjukkan bahwa tinggi rendahnya pendidikan responden tidak berhubungan dengan motivasi kebutuhan sosiologis dalam berusahatani tebu. Apapun tingkat pendidikan yang dimiliki oleh responden petani tidak akan berpengaruh pada motivasi kebutuhan sosiologis petani karena mereka lebih nyaman dapat bekerjasama ataupun bertukar pendapat dengan kerabat, tetangga, petani lain dan sebagainya.

Hubungan antara pendidikan dengan kebutuhan psikologis dapat dilihat dari nilai rs yang diperoleh sebesar 0,489 berada di antara batasan 0,26 sampai 0,50, dimana kondisi tersebut dinamakan dengan moderately low assocition. Selanjutnya hasil uji t untuk pendidikan dilihat dari nilai thitung sebesar 1,277 dan ttabel 2,160, sehingga diperoleh bahwa thitung 1,277 < ttabel 2,160 dan tingkat signifikansi 0,224 > 0,05 maka Ho diterima dan Ha ditolak, artinya tidak ada pengaruh signifikan antara pendidikan dengan motivasi kebutuhan psikologis. Hal ini menunjukkan bahwa tinggi rendahnya pendidikan responden tidak berhubungan dengan motivasi kebutuhan psikologis dalam berusahatani tebu. Karena petani tidak begitu menginginkan perubahan status sosial ataupun rasa ingin dihargai dan dihormati, petani merasa adanya perubahan status ataupun tidak bukan menjadi suatu permasalahan bagi petani yang berpendidikan lebih tinggi ataupun petani yang berpendidikan rendah.

\section{Hubungan dan Pengaruh antara Luas Lahan (X3) dengan Motivasi Kebutuhan Petani (Y)}

Hubungan antara luas lahan dengan kebutuhan fisiologis dapat dilihat dari nilai rs yang diperoleh sebesar 0,593 berada di antara batasan 0,51 sampai 0,75, dimana kondisi tersebut dinamakan dengan moderately high assocition. Selanjutnya hasil uji t untuk luas lahan dilihat dari nilai thitung sebesar -1,659 dan 
ttabel 2,160, sehingga diperoleh bahwa thitung -1,659 > ttabel -2,160 dan tingkat signifikansi 0,121 > 0,05 maka Ho diterima dan Ha ditolak, artinya tidak ada pengaruh signifikan antara luas lahan dengan motivasi kebutuhan fisiologis. Hal ini menunjukkan bahwa luas sempitnya lahan tidak berhubungan dengan motivasi kebutuhan fisiologis dalam berusahatani tebu.

Hubungan antara luas lahan dengan kebutuhan sosiologis dapat dilihat dari nilai rs yang diperoleh sebesar 0,239 berada di antara batasan 0,00 sampai 0,25, dimana kondisi tersebut dinamakan dengan no assocition. Selanjutnya hasil uji t untuk luas lahan dilihat dari nilai thitung sebesar 1,423 dan ttabel 2,160, sehingga diperoleh bahwa thitung 1,423 < ttabel 2,160 dan tingkat signifikansi 0,178>0,05 maka Ho diterima dan Ha ditolak, artinya tidak ada pengaruh signifikan antara luas lahan dengan motivasi kebutuhan sosiologis. Hal ini menunjukkan bahwa petani responden dengan lahan yang luas maupun sempit belum tentu berkeinginan untuk membantu secara sukarela terhapat petani lain. Bahkan petani hanya pasif menerima informasi yang diperoleh.

Hubungan antara luas lahan dengan kebutuhan psikologis dapat dilihat dari nilai rs yang diperoleh sebesar 0,237 berada di antara batasan 0,00 sampai 0,25, dimana kondisi tersebut dinamakan dengan no assocition. Selanjutnya hasil uji $t$ untuk luas lahan dilihat dari nilai thitung sebesar -0,397 dan ttabel 2,160, sehingga diperoleh bahwa thitung $-0,397>$ ttabel $-2,160$ dan tingkat signifikansi 0,698 > 0,05 maka Ho diterima dan Ha ditolak, artinya tidak ada pengaruh signifikan antara luas lahan dengan motivasi kebutuhan psikologis. Hal ini menunjukkan bahwa karena petani yang memiliki luas maupun lahan sempit tidak mempunyai keinginan yang sama untuk dihargai, dihormati dan menginginkan perubahan status yang lebih baik.

\section{Hubungan dan Pengaruh antara Pendapatan (X4) dengan Motivasi Kebutuhan Petani (Y)}

Hubungan antara pendapatan dengan kebutuhan fisiologis dapat dilihat dari nilai rs yang diperoleh sebesar 0,719 berada di antara batasan 0,51 sampai 0,75, dimana kondisi tersebut dinamakan dengan moderately high assocition. Selanjutnya hasil uji t untuk pendaptan dilihat dari nilai thitung sebesar 2,703 dan ttabel 2,160, sehingga diperoleh bahwa thitung 2,703 > ttabel 2,160 dan tingkat signifikansi 0,018 < 0,05 maka Ho ditolak dan Ha diterima, artinya ada pengaruh signifikan antara pendapatan dengan motivasi kebutuhan fisiologis. Hal ini sesuai dengan hipotesa kedua (H2) yang mengatakan bahwa terdapat pengaruh antara pendapatan dengan motivasi kebutuhan fisiologis. Hal ini menunjukkan bahwa pendapatan petani baik pendapatan kecil maupun pendapatan yang besar samasama memiliki keinginan untuk dapat meningkatkan kebutuhan fisiologi keluarga dan meningkatkan kesejahtraan keluarga.

Hubungan antara pendapatan dengan kebutuhan sosiologis dapat dilihat dari nilai rs yang diperoleh sebesar 0,204 berada di antara batasan 0,00 sampai 0,25, dimana kondisi tersebut dinamakan dengan no assocition. Selanjutnya hasil uji $\mathrm{t}$ untuk pendapatan dilihat dari nilai thitung sebesar -2,256 dan ttabel 2,160, sehingga diperoleh bahwa thitung $-2,256<$ ttabel $-2,160$ dan tingkat signifikansi 0,042 < 0,05 maka Ho ditolak dan Ha diterima, artinya ada pengaruh signifikan antara pendapatan dengan motivasi kebutuhan sosiologis. Hal ini sesuai dengan hipotesa kedua (H2) yang mengatakan bahwa terdapat pengaruh antara 
pendapatan dengan motivasi kebutuhan sosiologis. Hal ini menunjukkan bahwa tinggi ataupun rendahnya suatu pendapatan yang diterima petani dapat mempengaruhi motivasi kebutuhan sosiologis karena petani yang berpendapatan rendah memiliki keinginan atau dorongan untuk melakukan kerjasama ataupun bertukar pendapat dengan petani yang berpendapatan yang lebih tinggi, kerabat dan tetangga.

Hubungan antara pendapatan dengan kebutuhan psikologis dapat dilihat dari nilai rs yang diperoleh sebesar 0,324 berada di antara batasan 0,26 sampai 0,50, dimana kondisi tersebut dinamakan dengan moderately low Assocition. Selanjutnya hasil uji t untuk pendapatan dilihat dari nilai thitung sebesar 0,822 dan ttabel 2,160, sehingga diperoleh bahwa thitung 0,822< ttabel 2,160 dan tingkat signifikansi 0,426 > 0,05 maka Ho diterima dan Ha ditolak, artinya tidak ada pengaruh signifikan antara pendapatan dengan motivasi kebutuhan psikologis. Hal ini menunjukkan bahwa tinggi rendahnya pendapatan yang diterima petani tidak mmpengaruhi motivasi kebutuhan psikologis karena petani yang berpendapatan tinggi ataupun rendah sama-sama memiliki keinginan atau kemauan untuk bisa dihargai, dihormati, diakui oleh masyarakat atau petani yang lain dan memiliki status sosial yang setara.

\section{Hubungan dan Pengaruh antara Lingkungan Sosial (X5) dengan Motivasi Kebutuhan Petani (Y)}

Hubungan antara lingkungan sosial dengan kebutuhan fisiologis dapat dilihat dari nilai rs yang diperoleh sebesar $-0,083$ berada di antara batasan $-0,00$ sampai 0,25, dimana kondisi tersebut dinamakan dengan no assocition. Selanjutnya hasil uji t untuk lingkungan sosial dilihat dari nilai thitung sebesar $-0,490$ dan ttabel 2,160, sehingga diperoleh bahwa thitung $-0,490>$ ttabel $-2,160$ dan tingkat signifikansi 0,632 > 0,05 maka Ho diterima dan Ha ditolak, artinya tidak ada pengaruh signifikan antara lingkungan sosial petani dengan motivasi kebutuhan fisiologis. Hal ini menunjukkan bahwa lingkungan sosisal yang kurang mendukung akan membuat petani sulit untuk mengambil keputusan dalam berusaha tani tebu sehingga petani akan sulit untuk meningkatkan penghasilannya.

Hubungan antara lingkungan sosial dengan kebutuhan sosiologis dapat dilihat dari nilai rs yang diperoleh sebesar 0,576 berada di antara batasan 0,51 sampai 0,75 , dimana kondisi tersebut dinamakan dengan moderately high assocition. Selanjutnya hasil uji t untuk lingkungan sosial dilihat dari nilai thitung sebesar 3,972 dan ttabel 2,160, sehingga diperoleh bahwa thitung 3,972 > ttabel 2,160 dan tingkat signifikansi 0,002 < 0,05 maka Ho ditolak dan Ha diterima, artinya ada pengaruh signifikan antara lingkungan sosial dengan motivasi kebutuhan sosiologis. Hal ini sesuai dengan hipotesa kedua (H2) yang mengatakan bahwa terdapat pengaruh antara lingkungan sosial dengan motivasi kebutuhan sosiologis. Hal ini menunjukkan bahwa lingkungan sosial merupakan media petani untuk bisa saling mempererat kerjasama dan saling bertukar pendapat maupun informasi terkait mengenaik teknik berusahatani tebu.

Hubungan antara lingkungan sosial dengan kebutuhan psikologis dapat dilihat dari nilai rs yang diperoleh sebesar 0,217 berada di antara batasan 0,00 sampai 0,25, dimana kondisi tersebut dinamakan dengan no assocition. Selanjutnya hasil uji t untuk lingkungan sosial dilihat dari nilai thitung sebesar 1,338 dan ttabel 2,160, sehingga diperoleh bahwa thitung 1,338< ttabel 2,160 dan 
tingkat signifikansi 0,204 $>$ 0,05 maka Ho diterima dan Ha ditolak, artinya tidak ada pengaruh signifikan antara lingkungan sosial dengan motivasi kebutuhan psikologis. Hal ini menunjukkan bahwa mendukung atau tidaknya lingkungan sosial responden tidak berhubungan dengan kebutuhan psikologis dalam berusahatani tebu, karena kebutuhan psikologis hanya bisa dirasakan oleh dalam diri petani, kebutuhan psikologis dirasa sudah puas atau belum hanya pribadi petani sendiri yang bisa menilai.

\section{Hubungan dan Pengaruh antara Lingkungan Ekonomi (X6) dengan Motivasi Kebutuhan Petani (Y)}

Hubungan antara lingkungan ekonomi dengan kebutuhan fisiologis dapat dilihat dari nilai rs yang diperoleh sebesar $-0,070$ berada di antara batasan $-0,00$ sampai -0,25 dimana kondisi tersebut dinamakan dengan no assocition. Selanjutnya hasil uji t untuk lingkungan ekonomi dilihat dari nilai thitung sebesar 1,418 dan ttabel 2,160, sehingga diperoleh bahwa thitung -1,418 > ttabel -2,160 dan tingkat signifikansi 0,180 > 0,05 maka Ho diterima dan Ha ditolak, artinya tidak ada pengaruh signifikan antara lingkungan ekonomi dengan motivasi kebutuhan fisiologis. Hal ini menunjukkan bahwa tersedia atau tidaknya bibit, pupuk, pestisida dan jaminan harga di lingkungan sekitar tidak berhubungan dengan kebutuhan fisiologis. Meskipun lingkungan ekonomi tidak mendukung, petani akan tetap mencari jalan keluar agar usahatani tebu tetap berjalan, karena petani merasa dalam berusahatani tebu akan memperoleh keuntungan yang lumayan besar.

Hubungan antara lingkungan ekonomi dengan kebutuhan sosiologis dapat dilihat dari nilai rs yang diperoleh sebesar 0,221 berada di antara batasan 0,00 sampai 0,25 dimana kondisi tersebut dinamakan dengan no assocition. Selanjutnya hasil uji t untuk lingkungan ekonomi dilihat dari nilai thitung sebesar -0,119 dan ttabel 2,160, sehingga diperoleh bahwa thitung -0,119 > ttabel -2,160 dan tingkat signifikansi 0,907 > 0,05 maka Ho diterima dan Ha ditolak, artinya tidak ada pengaruh signifikan antara lingkungan ekonomi dengan motivasi kebutuhan sosiologis. Hal ini menunjukkan bahwa mendukung atau tidaknya lingkungan ekonomi yang tersedia atau tidaknya bibit, pupuk, pestisida, dan jaminan harga tidak menjadi suatu penghambat antara petani untuk saling bersosial dengan petani yang lain, bahkan dengan berinteraksi dengan petani yang lain bisa mendapat pemecahan masalah ataupun jalan keluar dari lingkungan ekonomi yang tidak mendukung tersebut.

Hubungan antara lingkungan ekonomi dengan kebutuhan psikologis dapat dilihat dari nilai rs yang diperoleh sebesar 0,060 berada di antara batasan 0,00 sampai 0,25 dimana kondisi tersebut dinamakan dengan no assocition. Selanjutnya hasil uji t untuk lingkungan ekonomi dilihat dari nilai thitung sebesar -0,335 dan ttabel 2,160, sehingga diperoleh bahwa thitung $-0,335>$ ttabel -2,160 dan tingkat signifikansi 0,743 > 0,05 maka Ho diterima dan Ha ditolak, artinya tidak ada pengaruh signifikan antara lingkungan sosial dengan motivasi kebutuhan psikologis. Hal ini menunjukkan bahwa mendukung atau tidaknya lingkungan ekonomi seperti adanya bibit, pupuk, pestisida, maupun jaminan hargadilingkungan sekitar tidak berhubungan dengan kebutuhan psikologis dalam berusahatani tebu, karena masing-masing petani mengahrapkan status yang lebih baik setelah berusahatani tebu. 


\section{Hubungan dan Pengaruh antara Kebijakan pemerintah (X7) dengan Motivasi Kebutuhan Petani (Y)}

Hubungan antara kebijakan pemerintah dengan kebutuhan fisiologis dapat dilihat dari nilai rs yang diperoleh sebesar 0,592 berada di antara batasan 0,51 sampai 0,75 dimana kondisi tersebut dinamakan dengan moderately high assocition. Selanjutnya hasil uji t untuk kebijakan pemerintah dilihat dari nilai thitung sebesar 0,641 dan ttabel 2,160, sehingga diperoleh bahwa thitung 0,641 < ttabel 2,160 dan tingkat signifikansi 0,533 > 0,05 maka Ho diterima dan Ha ditolak, artinya tidak ada pengaruh signifikan antara kebijakan pemerintah dengan motivasi kebutuhan fisiologis. Ada atau tidaknya bantuan yang diberikan oleh pemerintah seperti bantuan pupuk, pestisida kegiatan penyuluah dan pelatihan akan membuat petani tetap berusahatani tebu, karena dirasa dengan berusahatani tebu akan memberikan keuntungan dan meningkatkan ekonomi keluarga.

Hubungan antara kebijakan pemerintah dengan kebutuhan sosiologis dapat dilihat dari nilai rs yang diperoleh sebesar 0,174 berada di antara batasan 0,00 sampai 0,25 dimana kondisi tersebut dinamakan dengan no assocition. Selanjutnya hasil uji t untuk kebijakan pemerintah dilihat dari nilai thitung sebesar 0,419 dan ttabel 2,160, sehingga diperoleh bahwa thitung 0,419 < ttabel 2,160 dan tingkat signifikansi 0,682 > 0,05 maka Ho diterima dan Ha ditolak, artinya tidak ada pengaruh signifikan antara kebijakan pemerintah dengan motivasi kebutuhan sosiologis. Hal ini menunjukkan ada atau tidaknya fasilitas dari pemerintah, mendukung atau tidak mendukungnya kebijakan pemerintah tidak menjadi suatu penghambat petani untuk saling bersosial dan berinteraksi dengan petani yang lain dalam berusahatani tebu.

Hubungan antara kebijakan pemerintah dengan kebutuhan psikologis dapat dilihat dari nilai rs yang diperoleh sebesar 0,221 berada di antara batasan 0,00 sampai 0,25 , dimana kondisi tersebut dinamakan dengan no assocition. Selanjutnya hasil uji t untuk kebijakan pemerintah dilihat dari nilai thitung sebesar 0,049 dan ttabel 2,160, sehingga diperoleh bahwa thitung 0,049 > ttabel 2,160 dan tingkat signifikansi 0,962 > 0,05 maka Ho diterima dan Ha ditolak, artinya tidak ada pengaruh signifikan antara lingkungan sosial dengan motivasi kebutuhan psikologis. Hal ini menunjukkan bahwa tersedia atau tidaknya fasilitas dari pemerintah tidak berhubungan dengan kebutuhan psikologis dalam berusahatani tebu, karena petani sama-sama menginginkan memiliki status yang lebih baik sehingga petani akan berusaha secara mandiri untuk mencapai hal itu.

\section{Rekomendasi Untuk Meningkatkan Motivasi Petani Dalam Berusaha Tani Tebu}

Kendala yang dihadapi oleh petani baik dari faktor internal maupun ekstenal rata-rata adalah pendidikan, luas lahan, lingkungan ekonomi dan kebijakan pemerintah. Pendidikan yang rendah harus diprediksi untuk memacu motivasi petani yang ada, karena petani yang berpendidikan rendah maka akan sulit untuk memahami dan menerima pembaruan mengenai berusahatani tebu, dengan begitu peran pendidikan sangat penting bagi petani agar lebih memacu tingkat motivasi petani dalam berusahatani tebu. Kepemilikan lahan yang tidak besar bisa membuat petani memandang usaha tani yang dilakukan hanyalah sampingan, sehingga petani harus bisa menghindari luas dan sempitnya lahan yang mereka 
miliki agar para petani bisa konsisten berusaha tani tebu dengan tingkat motivasi yang baik. Lingkungan ekonomi yang tidak mendukung dapat menghambat motivasi petani dalam melakukan usaha tani tebu, oleh karena itu petani harus bisa menemukan alternatif untuk menghindari hambatan yang terjadi dalam lingkungan ekonomi tersebut. Kurangnya kebijakan dari pemeritah juga dapat mempengaruhi motivasi petani dalam berusaha tani tebu, pemerintah kabupaten seharusya bisa menyalurkan bantuan seperti pupuk, bibit, ataupun fasilitas pertanian yang diperlukan untuk meningkatkan motivasi petani dalam berusaha tani tebu. Selain itu, pemerintah kabupaten juga bisa menerapkan sistem glebagan dimana sistem pola tanam yang menerapkan pergantian komoditas tanaman, misalnya pada tahun ini petani berusahatani tebu maka tahun berikutnya petani harus berusahatani yang lain dan begitupun sebaliknya.

\section{KESIMPULAN}

Berdasarkan hasil penelitian dan pembahasan yang mengkaji motivasi petani dalam berusaha tani tebu di Desa Kertosari Kecamatan Asembagus Kabupaten Situbondo, maka dapat ditarik kesimpulan sebagai berikut:

1. Hubungan variabel faktor internal pembentuk motivasi dengan variabel motivasi kebutuhan petani yang hubungannya kuat adalah pendapatan dan luas lahan, sedangkan hubungan variabel faktor internal pembentuk motivasi dengan variabel motivasi kebutuhan petani yang tidak memiliki hubungan adalah pendidikan. Hubungan variabel faktor eksternal pembentuk motivasi dengan variabel motivasi kebutuhan petani yang hubungannya kuat adalah kebijakan pemerintah, sedangkan hubungan variabel faktor eksternal pembentuk motivasi dengan variabel motivasi kebutuhan petani yang tidak memiliki hubungan adalah lingkungan ekonomi.

2. Variabel faktor internal pembentuk motivasi yang berpengaruh signifikan terhadap variabel motivasi kebutuhan petani adalah pendapatan, sedangkan variabel faktor internal pembentuk motivasi yang tidak berpengaruh signifikan terhadap variabel motivasi kebutuhan petani adalah umur, pendidikan dan luas lahan. Variabel faktor eksternal pembentuk motivasi yang berpengaruh signifikan terhadap variabel motivasi kebutuhan petani adalah lingkungan sosial, sedangkan variabel faktor eksternal pembentuk motivasi yang tidak berpengaruh signifikan terhadap variabel motivasi kebutuhan petani adalah lingkungan ekonomi dan kebijakan pemerintah.

3. Rekomendasi alternatif untuk meningkatkan motivasi petani dalam berusahatani tebu adalah pendidikan petani harus tinggi, diharapkan kepemilikan lahan lebih luas, lingkungan ekonomi seperti jaminan yang stabil dan kebijakan pemerintah untuk menyalurkan bantuan seperti pupuk dan bibit serta fasilitas pertanian ditingkatkan.

\section{REFERENSI}

Badan Pusat Statistik. (2018). Statistik Tebu Indonesia 2018. BPS Indonesia

Husein Umar. (2013). Metode Penelitian untuk Skripsi dan Tesis Bisnis. Jakarta: Rajagrafindo Persada.

Mahi M. Hikmat. (2011). Metode penelitian: dalam perspektif ilmu komunikasi dan sastra. Yogyakarta: Graha Ilmu. 
Sadono Sukirno. (2006). Ekonomi pembangunan : proses, masalah, dan dasar kebijakan. Jakarta: Kencana.

Siegel, Sidney, Zanzawi Suyuti, \& Simatupang, Laudung. (2007). Statistik nonparametrik : untuk ilmu-ilmu sosial. Jakarta: Gramedia Pustaka Utama.

Singarimbun, M, \& Efendi. (1995). Metode Penelitian Survey. Jakarta: PT. Pustaka. 